\title{
MODERN THEOLOGICAL READING OF THE QUR'AN, AND GENDER ISSUES: THREE CASES OF FEMALE MUSLIM SCHOLARS
}

\author{
Kusmana \\ Syarif Hidayatullah State Islamic University (UIN) Jakarta \\ kusmana@uinjkt.ac.id
}

\begin{abstract}
In the last three decades a number of female Muslim scholars have been contributing to making Islam on gender discourse in modern era. This paper discusses three of them Amina Wadud, Asma Barlas, and Siti Musdah Mulia. They are considered of having one common ground in receiving modern ideas, in that they search for the true understanding of Islam by differentiating the understanding of Islam in the formative period from the similar understanding afterwards. In spite of having different use of modern ideas, they accept the basic assumption of democracy, human rights, feminism, and gender equity which put primary priority over the norm of right and freedom. They have the same way in framing their reading of the Qur'an (Islam) in relation to gender discourse, that is theological reading, putting tawhid as the basis of their approaches, yet each of them has her own procedures of readings. The paper finds that proposing productive readings over the discussed subject creates new ways of reading as well as new significations and meanings.
\end{abstract}

Keywords: theological reading, hermeneutics, the Qur'an, tawhid, and gender

\section{Introduction}

The West in the eye of Muslims is often seen as stepbrother sometimes in harmony, and some other times in quarrel, loving and hatred situation interchangeably happen between Muslims and the West over times. The West is often associated to Jew and Christianity. Jewish people and Christians are considered elder brothers because the two religions had the same source, and came earlier than Islam. In spite of being always in suspicious relation in terms of politics, in terms of knowledge, Muslim and the West actually always learn from one another. In their initial contact Muslims scholars learned from the West various sciences and developed them. While the West in the medieval period also learned from Muslim scholars by establishing centres for learning just Muslims did earlier. Though sometimes done quietly, and in fact the process of learning from each other takes place uninterruptedly, take-and-give relation in terms of knowledge nurtures positive relations between Muslims and the West. Having this in mind, this paper discusses one of the different groups of Muslim scholars (Stowasser: 18-21) in responding to the ideas of modernity coming from the West, taking theological reading about the issue of woman's leadership of family in the Qur'an as a case in point. The group is known as modernists. Barbara Freyer Stowasser defines them as "those scholars who differentiate the earliest understanding of Islam, and the life of the Prophet Muhammad and his Companions, from the manifestations emerged afterwards as results of the internationalization of Islam." (Stowasser:18) To exemplify the model of life of the formative period, modernists need new ijtihad or new reading up on Islamic teachings and heritages to produce a value system which is in accordance with or expected to be superior from modernity (Stowasser: 19).

Among modernists who were and are invited to do the task of providing 
Islamic perspective over the discourse of gender issues are Amina Wadud, Asma Barlas, and Siti Musdah Mulia. Their ideas are discussed here because they represent a model of independent reading from within as believers. It does not mean that other female Muslim scholars are not worthy to be discussed. The three are selected only as examples of theological reading of the Qur'an in modern context. A reading is scientific effort, and is supposed to be objective, a believing is religious expression, and it is likely subjective, inclining to protect and defend the belief. The three selected female scholars also claim that they read the Qur'an as believers. They claimed that they have tried their best to be objective in their reading. However we need to question their stances. How do they read the Qur'an with special reference to gender discourse? How do they tackle the barrier of the trapped of subjectivity as they read the discussed matter as believers?

\section{Methods}

Two kinds of method, and one key term, gender are needed are explained before the answer is discussed further: method of analysis of the paper itself, and method of hermeneutical reading used by the discussed three female scholars. I use a descriptiveanalytical analysis to answer the research questions. In so doing, I present as long as I can get the data what the three scholars present their ideas of Islamic (Qur'anic) perspective over gender issues. In addition I analytically contextualize their readings in the frame of how Muslim scholars respond to modernity. By doing these, I expect to be able to construct how the three female scholars try to formulate female Muslim scholar's perception where the place of woman in the Qur'an as well as in modern Muslim society should be.

Hermeneutical reading is an epistemological effort to construct knowledge by putting the subject matters in certain context to facilitate all possibilities of understanding to get new meaning and signification. The term is used here to discuss how a reader understands what God says about gender, and base his or her reading on Divine source (the Qur'an). This way of reading where an object is based on religious sources is called here as theological reading. Amina Wadud calls her method of analysis as hermeneutic of tawhid (Wadud, 1999: xii), Asma Barlas calls hers as unreading patriarchal interpretation of the Qur'an (Barlas, 2004), Siti Musdah Mulia calls hers as a contextual reading (Mulia: 41).

Wadud calls her hermeneutic of tawhid as a female inclusive reading of the Qur'an (Wadud, 1999: ix). She does not use the term tawhid in the sense of theological discipline, but uses it in its generic meaning, that is unity. Here, she intends to present the unity of the Qur'an's perspective about something (Wadud, 1999: xii). She is sure that by doing this a reader can arrive at the Qur'an's substantive message and guidance which is just and fair. She deploys three basic aspects of hermeneutical reading: 1. The Qur'an in which it was revealed, 2. How the Qur'an says what it says, 3. The worldview of the Qur'an (Wadud, 1999: 3). The first aspect of reading deals with the effort to search for the initial understanding of the Qur'an where it was accepted by the Prophet Muhammad and his Companions. The second tries to have a comprehensive understanding of the Qur'an's perception as well as prescription over something. The last one is a method to know what ontologically the Qur'an intends to inform to human being. By all three aspects of hermeneutical reading, she is sure that the Qur'an's message and guidance is still relevance with modern ideas of gender equity, justice, human rights, and democracy. All these processes of reading occupy requirements of a theological reading which characterizes by framing the object of reading in God's perspective. 
Barlas calls her method of reading the Qur'an as "unreading patriarchal interpretation of the Qur'an." She refers it to as Qur'anic hermeneutics. She defines it as "reading of God's Speech by connecting it to God." It means that God informs human beings of His knowledge for the benefit of Human beings themselves by relating all information God gives, in order an interpreter has a whole description of information. She calls this as "God's Self Disclosure."(Barlas, 2004: 13) God Self Disclosure is ontological hermeneutics where an interpreter or a reader examines all information of God's revelation in history. These information are treated as a paradigm or mode of thought in deciphering a discussed matter framed in the Qur'anic perspective. Barlas discusses three aspects of it which produces inclusive readings of the Qur'an: the principle of Divine Unity, Justness, and Incomparability (Barlas, 2004: 13). First is the principle of Divine Unity. It may be defined as a conviction that there is no god but Allah, Muhammad, the Messenger of Allah. It has great implication for Qur'anic hermeneutics. This principle of tawhid reasserts that God is absolute sovereign which is indivisible into any gender. It means that there is no any privilege of any gender. God is superior over others (Barlas, 2004: 13-4). The second is Justness. It may be defined as God's principle of impartiality. The way that God implements His impartiality is "severe, rigid, and unrelenting," but God never does zulm or improper act, including discriminates any gender or prescribes misogyny for somebody (Barlas, 2004: 14). Lastly, the third is Incomparability. It may be defined as a belief that God is not the same with others, and not be compared with others. She identifies it as "unrepresentable, especially in anthropomorphic terms." By saying this, she asserts that the Qur'an tirelessly and emphatically rejects God's sexualization or engenderment (Barlas, 2004: 14-5).

By framing the explanation of tawhid in this sense, she shows readers that Qur'anic hermeneutics proposes ontological God's perception about gender which is just and fair. Regarding verses which are literally contradictive each other, Barlas gives them a holistic reading by relating them to these three fundamental aspects to facilitate rendering what so called by Fazlur Rahman as "moral-social objectives of the Qur'an."(Esack : 66)

Siti Musdah Mulia calls hers as a contextual reading. It may be defined as a method which considers the importance of background and context where and when the Qur'an was revealed, and read by readers over generations, and of the context of readers. It asserts that Islam is a peaceful and respectful religion for human being and universe (Mulia: 9). In doing so, she identifies factors in the history of Islam as well as the fundamental sources of Islam -the Qur'an and the Sunnah. She frames her method in the principles of tawhid. In her view tawhid is liberating, treating gender relation just and equal. In applying the tawhid principle a Muslim reader is prescribed to be just to family, to anyone else when she or he has to solve problem, to other people whom you are dislike or hate, and to orphans in managing their wealth (Mulia, 2005: 20-21). In addition, by holding tawhid as norm, the relation among people in faith is framed in brotherhood in Islam(Mulia, 2005: 34-35). Similar with Barlas and Wadud, by constructing the understanding of Islam in this scheme, Mulia tries to show us perception as well as pieces of practices which are just and equal with regard to gender relations. In her view, these are capital in which a reader can construct a concept of equal gender relations in Islam.

\section{Gender: Definition, Patriarchy, and QS. 4: 34}

Gender is a category of analysis which treats gender relations equal, considering inequalities of gender relations in societies as socially constructed. 
Refining the earlier concept of feminism in which patriarchal system are dominantly operative and maintained, gender analysis consider similar targets, but with the stand that social relations can be transformed into more equal relations following the existing constructing and deconstructing values systems (Walker: 39; Sugihastuti and Septiawan: 3-13). In so doing, a researcher can identify status, role, behaviour, mentality, and emotional characteristics which cause inequalities (Mulia: 55). A researcher can identifies these inequalities by identifying internal and external factors that bring about those inequalities.

Patriarchy may be defined as "society, country, etc., with a patriarchal system or government" (a system which is ruled or controlled by men). It can be specifically refer to a culturally explicit method of rule by men, or to a politics of sexual variation which put men superior over women (Barlas: 11-12).

The QS. al-Nisâ' $/ 4$ : 34 serves as a case in point in illustrating the discussion of theological reading of the Qur'an in relation to gender. The Qur'an uses the term qawwämūna to refer to leadership. In the same chapter it applies qawwāmina (QS. 4: 135) referring to justice perpetrators. The same word is also found in QS. 5: 8, and it means as truth custodians. The word itself according to Baalbaqi (1994) can be meant as care taker, custodian, guardian, curator, keeper, supervisor, superintendent (Baalbaqi, 1994: 876). Louis Malouf (1975) translates qawwām as al-mutakaffilu bi al-amri (responsible for something), al-qawiyyu alā al-qiyām bi al-amri (capable of doing something such as management), or al-amīr (leader) (Malouf, 1975: 663-664).

Munāsabah al-äyāt or relation between this verse with the verse(s) before and after is generally about family life where before QS. 4: 34, the Qur'an [QS. 4; 33] emphasizes the importance of respect one another, and after [QS. 4: 35] it offers way of solving family problem where the third party or juror can be asked to mediate their problem. The QS. 4: 34 itself describes how a spouse is stated to take leadership in the family when in fact the spouse is the breadwinner of the family and when a problem occurs, the spouse should take a measured step keeping in mind that all approaches taken should be in educational tone, keeping the harmony of the family.

According to al-Ṭabarī, the asbab al-nuzul of the verse was related to a question posted to Muhammad by Ummu Salamah, one of his wives, regarding the share of inheritance for a woman which was only half that of man's share (Hanafi, 2012: $14,18)$.

\section{Discussion}

Wadud, Barlas, and Mulia all have the same idea regarding the need of new understanding of the Qur'an in modern context. They all recognize that people live today is a lot better than people lived in the time of revelation, medieval period or prior to modernity where Muslim societies were very much occupied with traditional way of life in which women were still classified as subordinated. Wadud call this need as the gender jihad as a Muslim woman (Wadud, 1999: x), Barlas names it as a challenge for oppressive reading of the Qur'an (Barlas, 2004: 11), and Mulia entitles it as an effort to "change culture which is discriminative and unequal towards women with the one which is in accordant with Islamic teachings."(Mulia: 9) Barlas, and Mulia are critical over the use of Hadith and Sunnah, quoting them as necessary, and with clarification. Barlas discusses this source in methodological level, whereas Mulia takes advantages from it in many of her discussion. For example, a Hadith narrated by Abi Bakrah which says that if a society is led by a woman, this society will be misfortune, is used to illustrate an improper quotation, as well as a proof of objective situation (Mulia, 2005: 296, 306). Wadud, on the other hand, puts a lot emphasis on verses of the Qur'an in 
presenting her arguments of equality in the Qur'an.

Wadud, Barlas, and Mulia all discuss QS.4: 34, but each of them has certain way of reading it regardless that they all deploy a theological hermeneutical reading of it. Wadud frames her discussion of QS. 4: 34 in discourse of rights and role of woman in which she finds that the context when and where the Qur'an was revealed was patriarchal. She means it as "a culture built on a structure of domination and subordination .... which demands hierarchy."(Wadud, 1999: 80) This norm became the background which has been influencing readers and interpreters of the Qur'an. The Qur'an itself informs universal messages as well particular ones. Wadud sees the Qur'an as a whole which reflects its universal or main spirit of the God's message. This part is a parameter, whereas verses which inform particular information connect to the receivers of the Qur'an in which its initial revealed audience was patriarchal. Having explained the first hermeneutical analysis, she then illustrates two other steps of hermeneutical analysis, mentioned above: linguistic explanation, and the Qur'an's worldview. She argues that the term darajat, faddala, and qawwamu ala can be more appropriately read as neutral or objective. It means that the verse infers man as leader in the family when all requirements to protect, to manage, and to lead are possessed by a spouse (man). In the case of the more qualified spouse is a wife, then leadership is more appropriately handed down to her. Existing interpretations which prefer men as leaders in the family, in her opinions were influenced by patriarchal values which had been operative dominantly since revelation till second half of the $20^{\text {th }}$ century(Wadud, 1999: 62-82).

Mulia discusses QS. 4: 34 in extended discourse, the religion of Islam in which it respects equality and unity of human beings. What differentiates one another is one's taqwa towards Allah, and only Allah who has the right to judge whom (Mulia: 3-4; 2005: 3). As she understands patriarchy which has been embedded in Islamic civilization for quite a long time has been socially constructed, she believes that Islam including the Qur'an actually prescribes equality. This norm is actually not alien in Islam and its history, precedencies and practices of it can be found. It is therefore, she reads QS. 4: 34 not as many Muslim scholars who were influenced by medieval norms, but as other modernists who frame the verse in objective situation depending on the fulfillment of qualified agent. Today situation has been changed a lot better in various terms ranging from education, social system, information system, law, to political system. If a husband is the one who fulfils them, then he is entitled to be head of the family. If the case is vice versa, then, she is entitled (Mulia, 2005: 307-308).

Barlas goes further in elaborating her theory of unreading patriarchal interpretation of the Qur'an. In so doing, she borrows contemporary theory of understanding, productive hermeneutical reading. As QS. 4: 34 is the verse about family, she frames it in the scheme of family and marriage where the term of mother, father, daughter, husband, wife, adultery, and polygyny are discussed. The way she discusses them is by comparing them with similar concept in the West (Barlas, 2004: 167-202). Patriarchy has rooted almost everywhere before the coming of Islam, after the death of the Prophet Muhammad, occupied dominantly in mediaeval period, and retained up present with radical challenge from the modern model of family and marriage which were nurtured by the idea of rights, justice, and equality. She looks for the kinds of these values in Islam and more exact in the Qur'an, in this case in QS. 4: 34 in which she finds that it is the real nature of it: the Qur'an is egalitarian, and antipatriarchal system. In her view, when the Qur'an talks about patriarchal aspect in its verses including in the QS. 4: 34, it uses specific term, "address," and not "advocate." It means that the Qur'an does deals with it wisely. In her words, the Qur'an restricts patriarchal practices 
with humanistic approaches(Barlas, 2004: 6).

How she applies her reading of this case, Barlas ontologically starts from the fact that all the texts are polysemic, open to variant readings. The Qur'an, including QS. 4: 34 is the real of hermeneutics, and located in the extratextual contexts where possibilities to produce significations and meanings are open. In addition, as the Qur'an deals with patriarchal issues, it is open for any kind of readings including egalitarian as well as patriarchal readings. The Qur'an becomes the site for negotiation or even competition to gain more accepting readers for modern meaning of the Qur'an. In short, she tries to propose a model of reading in which it is considered more suitable for modern audience that have more equal gender relations(Barlas, 2004: 183-189). She concludes her explanation over the verse as follows:

"The fact that there are so many different readings of this Âyah means that it is ambiguous, and to that extent, we should be willing to rethink our commitment to its centrality in our own understanding of the Qur'an's teachings, as well as to an exegesis that reads sexual inequality and husband privilege into the Qur'an. In this context, even if we cannot all agree on the most suitable reading, we should be able to admit that reading this Āyah as a license to batter wives, or to compel obedience upon them, is not acceptable in that it is not the best meaning we can derive from the Qur'an. Moreover, it contradicts the Qur'an's view of sexual equality and its teachings that marriage should be based in love, forgiveness, harmony, and sukūn.” (Barlas, 2004: 189)

In spite of the compelling classical interpretation of QS. 4: 34 which retains men's superiority over women due to God's order, men's positions as breadwinners, and protectors, as well as woman's nature or kodrat of weaker human being, the three examples of alternative readings of the verse reflect new criticism which seeks for new model of gender relations which call for a new basis of loving, and harmony in family life which based on respect, justice, and equality.

\section{Conclusion}

Having discussed above, we can conclude that Amina Wadud, Asma Barlas, and Siti Musdah Mulia try to propose a modern Quranic narration of gender discourse which is just and equal. They consider it important to be offered in modern era, in order to provide Muslims systems and values that are dear, and relevant to them. They made serious endeavor to objectify their elaborations by exploring Islamic heritages as well as borrowing Western tradition of analysis which facilitates scientific subjective way of reading, i.e. productive hermeneutics in the case of Wadud, and Barlas, and general scientific analysis, contextual reading, in the case of Mulia. Of the models of readings proposed by the three examples of Muslim female scholars, Barlas's model of reading, in my view deserves further appreciation as she has adequately provided an independent model of reading the Qur'an, and open to be enriched by the existing models of interpretation of the Qur'an such as thematic approach, and tafsir maqasidi in which both are interdisciplinary in nature. The strength of Wadud's proposal is in her work's position as being the first attempt in paving the way of new reading the Qur'an and gender. Finally, the contribution of Mulia lien on her play of bravery agency of posing different view on gender equality in the midst of still nurtured dominant norm of patriarchy of her Indonesian context.

\section{Reference:}

Baalbaqi, Rohi. 1994. Al-Maurid: A Modern Arabic English Dictionary. Beirut: Dar El-Ilm Lilmamalayin. 
Barlas, Asma. 2004. Believing Women in Islam: Unreading Patriarchal Interpretations of the Qur'an. Austin, University of Texas Press.

Esack, Farid. Qur'an Liberation \& Pularalism. Oxford: Oneworld.

Hanafi, Muchlis Muhammad (et.al). 2012. "Pendahuluan" in Kedudukan dan Peran Perempuan. Jakarta: Kementrian Agama RI.

Malouf, Louis. 1975. al-Munjid fì al-Lughah wa al-A 'lam. Beirut: Dar el-Mashreq.

Muhammad, Husein. 2007. Fiqh Perempuan: Refleksi Kiai atas Wacana Agama dan Gender. Yogyakarta: LKiS.

Mulia, Siti Musdah. Muslimah Sejati: Menempuh Jalan Islami Meraih Ridha Ilahi. Bandung: Marja, Islam \& Inspirasi Kesetaraan Gender. Yogyakarta: Kibar Press.

, (2005). Muslimah Reformis: perempuan Pembaharu Keagamaan, Bandung: Mizan.

Syafruddin, Didin. 1994. "Argumen Supremasi atas Perempuan: Penafsiran Klasik QS alNisaā': 34," in Ulumul Qur'an: Jurnal Ilmu dan Kebudayaan. No. 5 dan 6. Vol. V, Th. 1994, pp. 4-10.

Stowasser, Barbara Freyer. Reinterpretasi Gender: Wanita dalam al-Qur'an, Hadis, dan Tafsir. Jakarta: Pustaka Hidayah.

Sugihastuti, and Itsna Hadi Septiawan, Gender dan Inferioritas Perempuan: Praktikpraktik Sastra Feminis, Yogayakarta: Pustaka Pelajar.

Wadud, Amina. 1999. Qur'an and Woman: Rereading the Sacred Text from a Woman's Perspective. Newyork and Oxford.

Walker, Victoria. "Feminist Criticism, Anglo-American, " in Encyclopedia of Contemporary Literary Theory: Approaches, Scholars, Terms. Toronto, Buffalo, London: University of Toronto Press. 